\title{
Accounting
}

\section{Audit efficiency and board activity in Saudi Arabia: Empirical investigation}

\author{
Khaled Salmen Aljaaidi $^{a^{*}}$, Omar Ali Bagais ${ }^{a}$ and Sultan Abdullah AlAbdullatif ${ }^{b}$
}

${ }^{a}$ Department of Accounting, College of Business Administration, Prince Sattam bin Abdulaziz University, Saudi Arabia ${ }^{b}$ Accounting Department, College of Business Administration, Umm Alqura University, Saudi Arabia

\section{H R O N I C L E}

Article history:

Received: November 28, 2020

Received in revised format:

December 282020

Accepted: January 20, 2021

Available online:

January 23, 2021

Keywords:

Board activity

Audit efficiency

Saudi Arabia

\section{A B S T R A C T}

The aim of this study is to empirically examine the association between audit efficiency and board activity among listed energy companies in Saudi Stock Exchange (Tadawul) for the period 20122019. The final sample of this study consists of 32 firm-year observations. Using the Pooled OLS regression, the study finds that audit efficiency was positively related to board activity. Moreover, the result indicates the complementary role of monitoring mechanisms in which audit efficiency complements the board activity. The study also provides insightful evidence to policy makers on the link of audit efficiency and board activity among energy companies.

\section{Introduction}

(C) 2021 by the authors; licensee Growing Science, Canada

The focus of this study is to examine how audit efficiency may influence the activity of the board meeting frequency among energy listed companies in Saudi Arabia for the period 2012-2019. Findings of various research studies have established that the number of board meetings plays a critical role in determining the level of the board monitoring efficacy. Essentially, board meetings provide directors with ample opportunity to perform and coordinate their duties with ease. Moreover, the board meetings create a conducive working environment and principal occasions when the directors can formally conduct monitoring management effectively (Baccouche \& Omri, 2014; Jiraporn et al., 2009; Conger et al., 1998; Vafeas, 1999; Brick \& Chidambaran, 2010; Ramos \& Olalla, 2011; Agrawal \& Knoeber, 2001; Agrawal \& Knoeber, 2001). The frequency of board meetings is widely viewed in the current literature as an alternative to the level of observing service delivery (Greco, 2010; Collier and Gregory, 1999; Vafeas, 1999; Laksmana, 2008; Sharma et al., 2009). Additionally, the frequency of board meetings can be considered as a proxy for the time directors have to conduct their monitoring role as well as the level of activity delivery monitoring (Greco, 2010; Vafeas, 1999; Carcello et al., 2002; Laksmana, 2008). Several empirical studies examined the board meeting frequency with different issues in the marketplace (Greco, 2010; Vafeas, 1999; Hahn, 2007; Baccouche and Omri, 2014; Hahn \& Lasfer, 2016; Lin et al., 2014; Menon \& Williams, 1994), ignoring the impact of audit report delay. Essentially, companies wait for the issuance of the auditing report before pronouncing their earnings (Bamber et al., 1993). Generally, this means that it is incumbent upon the individual companies to promote timeliness provision of financial reports. It is considered an important element in sharing vital financial information of a given company with the market and is closely associated with

* Corresponding author.

E-mail address: k.aljaaidi@psau.edu.sa (K. S. Aljaaidi) 
market responses (Ferreira et al., 2011; Dopuch et al., 1986; Al-Najjar, 2012; Chambers \& Penman, 1984). According to AlAjmi (2008), most shareholders in the emerging markets demographic, especially in developing countries, largely depend on financial reporting as the primary source of information. As such, this study intends to examine the effects of the delayed audit report on the activities of the board. Yet, to the best of the researcher's knowledge, no empirical evidence exists that allows conclusive determinations to be made of how the delay of audit report influences the board meeting frequency in the context of Saudi Arabia. This study contributes to the existing literature in several ways. First, this study examines the association of the audit report delay on board meeting frequency. We provide an additional empirical evidence on the link between audit report delay and board meeting frequency. Second, this study is conducted in the setting of Saudi Arabia which is characterized as a context having a paucity of research. Finally, the sample of this study is the energy companies which is considered an important sector in the Saudi market that has been ignored as a sole industry in the empirical investigations.

The rest of the paper continues as follows. The next section briefly reviews the extant literature and formulates the hypotheses. The third section describes the research design. The empirical results are reported in the fourth section while in the final section, conclusions are drawn.

\section{Literature Review and Hypotheses Development}

Evidence reveals that auditors form an integral part of corporate governance, especially in countries with relatively weak legal institutions. Worthwhile noting is that the auditors' ability to conduct an exhaustive financial audit and discover mismanagement of public funds is vital in the fight against corruption. In effect, higher-quality auditors play an effective monitoring role and help in reducing agency problems as compared with the low-quality auditors (Choi \& Wong, 2007; Beattie \& Fearnley, 1995; DeFond, 1992; Ashbaugh \& Warfield, 2003). External auditors play an essential monitoring role in corporate governance (Allen et al., 2005; DeFond et al., 2000; Raghunandan \& Rama, 2007) since stakeholders' demand reliable financial information (Ashbaugh \& Warfield, 2003). Audit efficiency refers to the auditor's ability to minimize audit-related costs while achieving audit goals on time without compromising the quality of the audit report (Bamber et al., 1993; Pincus et al., 1999; Abbott et al., 2012; Knechel \& Sharma 2012; Knechel et al., 2012; Kaplan \& Williams, 2013; Blankley et al. 2014; Al-Daoud et al., 2016).

Newton and Ashton (1989) and Afify (2009) assert that timeliness of financial reporting is considered a key indicator of better auditing outcomes. As such, it is incumbent upon auditors to provide accurate auditing reports on time. A timely audit report is essential as several companies rely on the auditor's report to declare their financial report (Bamber et al., 1993). This means that timing is an essential element in financial reporting regarding the sharing of important financial information with the market and is closely related to market responses (Dopuch et al., 1986; Coles et al., 2008; Chambers \& Penman, 1984). Al-Ajmi (2008) reports that shareholders in the emerging countries rely on financial reporting as a main source of information. Khasharmeh and Aljifri (2010) add that audit reports are critical for upcoming economies as a media release, news conferences, and financial analysts' forecasts are not fully established (Wallace \& Briston, 1993; Chahine \& Tohme, 2009; Lipton \& Lorsch, 1992). For better outcomes, shareholders make their decisions based on timely published and audited financial reports (Piot et al., 2015). Consequently, several empirical studies have been conducted to examine the board meeting frequency with various factors in the marketplace (Greco, 2010; Vafeas, 1999; Hahn, 2007; Baccouche \& Omri, 2014; Hahn \& Lasfer, 2016; Lin et al., 2014; Fama \& Jensen, 1983), ignoring the impact of audit report delay. However, to the best of the researchers' knowledge, a study linking empirically the audit report lag with board meeting frequency does not exist. This issue has been ignored by the researchers of audit report lag in the context of corporate governance monitoring mechanisms.

It is argued by previous studies that corporate governance mechanisms may substitute or complement each other (Cai et al., 2009; Byrne, 1996; Davis \& Useem, 2002; Rediker \& Seth, 1995; Ward et al., 2009). In this regard, as audit report lag is an indicator for an audit efficiency, external monitoring mechanism, and board activity, an internal monitoring mechanism, the association between these two monitoring mechanisms have not yet been tested whether they play a substitution or a complementary role. In specific, the more time and effort spent on auditing the financial statements may delay issuing the audit report which, consequently, may increase the audit fees. This might affect negatively the investors' confidence and increase the overall monitoring costs, and as a result, the agency cost will increase. Based on the above discussion evidencing the positive direction of the association between the audit efficiency and board activity, we formulate the following hypotheses:

$H_{1}$ : Audit efficiency is related positively to board activity.

$\mathrm{H}_{2}$ : Audit efficiency complements and not substitutes the board activity.

\section{Research design}

We construct our sample by selecting energy companies listed on Saudi Stock Exchange (Tadawul) from 2012 to 2019 that disclose information on board meetings and audit report delay. The information related to board meetings and audit report delay 
was collected by hand from financial statements. Our final sample comprises 5 energy companies with complete data, resulting in 32 firm-year observations.

To examine the association between audit efficiency and board activity, a multiple regression model was specified that links these variables and control for other several variables that are evidenced by the extant research of their influence on the board activity. Pooled Ordinary least square model OLS was specified to examine the association of audit report delay with board activity $B D A C T$.

$$
B D A C T=\beta_{0}+\beta_{1} A E F+\beta_{2} F S I Z E+\beta_{3} F L E V+e
$$

where:

$\begin{array}{ll}B D A C T & =\text { Number of meetings held during the year } \\ A E F & =\text { A number of calendar days from fiscal yearend to the date of the auditor's report } \\ \text { FSIZE } & =\text { Total assets } \\ \text { FLEV } & =\text { Debt to equity ratio } \\ e & =\text { error term. }\end{array}$

As for the measurements of the variables, Table 1 exhibits the dependent and test variables.

Table 1

Summary of the Operationalization and the Expected Sign of the Research Variables

\begin{tabular}{|c|c|c|c|}
\hline Variables & Acronym & Operationalization & $\begin{array}{l}\text { Coefficient } \\
\text { Predictions }\end{array}$ \\
\hline \multirow{2}{*}{\multicolumn{4}{|c|}{ Dependent Variable }} \\
\hline & & & \\
\hline Board activity & $B D A C T$ & Number of meetings held during the year & d.v \\
\hline \multicolumn{4}{|l|}{ Test variable } \\
\hline Audit Efficiency & $\mathrm{AEF}$ & $\begin{array}{l}\text { A number of calendar days from fiscal yearend to the date of } \\
\text { the auditor's report }\end{array}$ & i.v \\
\hline \multicolumn{4}{|l|}{ Control Variables } \\
\hline Firm size & FSIZE & Total assets & \\
\hline Financial leverage & FLEV & Debt to equity ratio & \\
\hline
\end{tabular}

The board meeting frequency model used in this study is an extension of the previous studies (Greco, 2010; Vafeas, 1999; Hahn, 2007; Baccouche \& Omri, 2014; Hahn \& Lasfer, 2016; Lin, Yeh \& Yang, 2014). We include two control variables that have been previously evidenced to have an association with board meeting frequency. Firm size FSIZE is found to have a significantly positive association with board meeting frequency (Greco, 2010; Hahn, 2007; Brick \& Chidambaran, 2010; Lin, Yeh and Yang, 2014; Baccouche and Omri, 2014). Firm leverage FLEV is reported to have a significantly positive association with board meeting frequency (Greco 2010; Baccouche \& Omri, 2014; Hahn \& Lasfer, 2016; Haniffa et al., 2006)

\section{Empirical Results}

Table 2 shows the descriptive statistics of the variables. It depicts the mean, standard deviation, minimum and maximum of each variable in the sample data set.

Table 2

Descriptive statistics

\begin{tabular}{lcccc}
\hline & Mean & Minimum & Maximum & Std.Deviation \\
\hline BDACT & 6 & 4 & 10 & 0.991 \\
AEF & 49 & 15 & 89 & 19.790 \\
FSIZE & 18872179084 & 309984124 & 74029648000 & 23262872571.872 \\
FLEV & 1.805 & .01 & 6.370 & 1.961 \\
\hline
\end{tabular}

Table 2 displays that there is a significant range of variation among the considered sample of this study. It is shown that the range of $B D A C T$ is from 4 to 10 with an average of 6 and a standard deviation of 0.991 . The mean of AEF is 49 days with a 
minimum of 15 days and a maximum of 89 days and a standard deviation of 19.790 days. The average of the FSIZE is 18872179084 with a minimum of 309984124 and a maximum of 74029648000 and a standard deviation of 23262872571.872 . The mean of FLEV is 1.805 with a maximum of 6.370 and a minimum of .01 and a standard deviation of 1.961 . The range of $P E$ is from .00 to .11 with an average of .042 and a standard deviation of 1.961 .

Table 3

Correlation matrix of independent variables

\begin{tabular}{lccc}
\hline & AFE & FSIZE & FLEV \\
\hline AEF & 1 & & \\
FSIZE & .256 & 1 & 1 \\
FLEV & .698 & $.740^{* *}$ & 1 \\
\hline
\end{tabular}

As shown by Table 3, the correlation matrices verify that no multicollinearity exists among the variables, as none of the variables correlates above 0.90 . All the variables have a correlation of equal to or less than .740 .

Table 4 reports the estimated model coefficients, the associated significant test results, the adjusted $R^{2}$ and the $F$-value for the board activity model. The $F$-value for the model is statistically significant at the $1 \%$ level, indicating that the overall model can be interpreted. The adjusted $R^{2}$ is .307 , indicating that the model has explained $30.70 \%$ of the variance in the board activity. This indicates a good fit of the board activity model.

Table 4

Pooled OLS Analysis Results

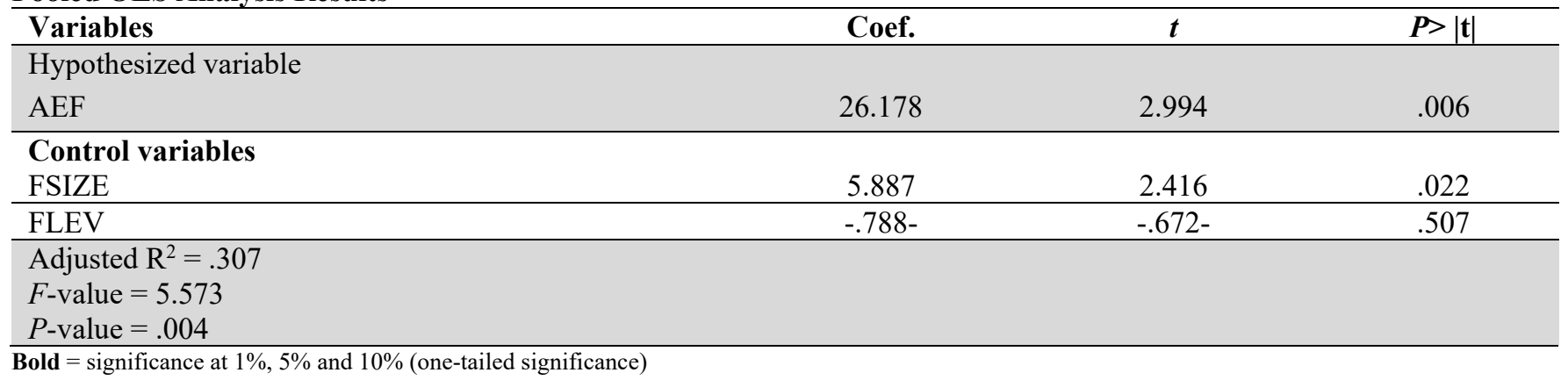

Tables 4 displays that audit efficiency $A E F$ is related positively to board activity $B D A C T$ ( $p$-value $<0.006$, one-tailed significance). This result indicates that the higher the audit report is delayed, the more the board meetings are held. Therefore, hypothesis $\mathrm{H}_{1}$ is accepted. Further, this result indicates that audit efficiency complements the board activity. Thus, hypothesis $\mathrm{H}_{2}$ is supported. In particular, the results of this study confirms that the more time and effort spent on auditing the financial statements indicates the increase on the overall monitoring costs, and as a result, the agency cost will increase. As a consequence, the board of directors increases their meetings to mitigate these problems, maintain the investors' confidence, and face the increased pressure to enhance its oversight activities.

\section{Conclusion}

The purpose of this study was to examine the relationship between audit efficiency and board activity among listed energy companies in Saudi Arabia. The final sample consists of 32 firm-year observations covering the period 2012-2019. The Pooled OLS regression results reveal that audit efficiency is positively related to board activity. In addition, audit efficiency as an external monitoring device complements the board activity which is an internal monitoring mechanism. This confirms that the more time and effort spent on auditing the financial statements indicates the increase on the overall monitoring costs, and as a result, the agency cost will increase. As a consequence, the board of directors increases their meetings to mitigate these problems, maintain the investors' confidence, and face the increased pressure to enhance its oversight activities.

This study will provide vital information that will help bridge the knowledge gap in the existing literature on board activities. The study will also be critical in the literature investigating the connection between board activity and audit efficiency. Additionally, the findings of this study might have practical implications for the Saudi stock market (Tadawul). These practical implications might gain new understanding regarding the extent to which the board of companies dealing in energy is active in such a way to practice their role of monitoring in protecting the interests of shareholders. Additionally, the external auditors and 
the companies' management team will find the findings beneficial in understanding how the audit efficiency might influence the activities of the board.

This study acknowledges several limitations. First, the sample of the study consists of energy companies. Future research could include other industries such as the petrochemical sector, telecommunication sector and so far, second, this study examined one external monitoring mechanism as an independent variable. Future lines of research could include other corporate governance determinants such as board size, board independence, CEO duality, audit committee attributes, ownership types and audit quality. Finally, this study is carried out in the Saudi setting. Future lines of research could replicate the same model in different GCC countries and other Middle East countries.

\section{Acknowledgement}

This publication was supported by the Deanship of Scientific Research at Prince Sattam bin Abdulaziz University, Alkharj, Saudi Arabia.

\section{References}

Agrawal, A., \& Knoeber, C. R. (2001). Do some outside directors play a political role?. The Journal of Law and Economics, 44(1), 179-198.

Al-Ajmi, J. (2008). Audit and reporting delays: Evidence from an emerging market. Advances in Accounting, 24(2), 217-226.

Al-Daoud, K. I., Saidin, S. Z., \& Abidin, S. (2016). Board meeting and firm performance: Evidence from the Amman stock exchange. Corporate Board: Role, Duties and Composition, 12(2), 6-11.

Allen, R. D., Hermanson, D. R., Kozloski, T. M., \& Ramsay, R. J. (2006). Auditor risk assessment: Insights from the academic literature. Accounting Horizons, 20(2), 157-177.

Al-Najjar, B. (2012) The determinants of board meetings: evidence from categorical analysis. Journal of Applied Accounting Research, 13, 178-90.

Ashbaugh, H., \& Warfield, T. D. (2003). Audits as a corporate governance mechanism: Evidence from the German market. Journal of International Accounting Research, 2(1), 1-21.

Baccouche, S., Hadriche, M., \& Omri, A. (2014). Multiple directorships and board meeting frequency: Evidence from France. Applied Financial Economics, 24(14), 983-992.

Bamber, E. M., Bamber, L. S., \& Schoderbek, M. P. (1993). Audit structure and other determinants of audit report lag: An empirical analysis. Auditing, 12(1), 1.

Beattie, V., \& Fearnley, S. (1995). The importance of audit firm characteristics and the drivers of auditor change in UK listed companies. Accounting and Business Research, 25(100), 227-239.

Blankley, A. I., Hurtt, D. N., \& MacGregor, J. E. (2014). The relationship between audit report lags and future restatements. Auditing: A Journal of Practice \& Theory, 33(2), 27-57.

Brick, I. E., \& Chidambaran, N. K. (2010). Board meetings, committee structure, and firm value. Journal of Corporate Finance, 16(4), 533-553.

Byrne, J. (1996). The National Association of Corporate Directors' New Guidelines Won't Tolerate Inattentive, Passive Uninformed Board Members. Business Week, 25.

Carcello, J. V., Hermanson, D. R., Neal, T. L., \& Riley Jr, R. A. (2002). Board characteristics and audit fees. Contemporary Accounting Research, 19(3), 365-384.

Chahine, S., \& Tohmé, N. S. (2009). Is CEO duality always negative? An exploration of CEO duality and ownership structure in the Arab IPO context. Corporate Governance: An International Review, 17(2), 123-141.

Chambers, A. E., \& Penman, S. H. (1984). Timeliness of reporting and the stock price reaction to earnings announcements. Journal of Accounting Research, 22(1), 21-47.

Choi, J. H., \& Wong, T. J. (2007). Auditors' governance functions and legal environments: An international investigation. Contemporary Accounting Research, 24(1), 13-46.

Coles, J. L., Daniel, N. D., \& Naveen, L. (2008). Boards: Does one size fit all?. Journal of Financial Economics, 87(2), 329356.

Collier, P., \& Gregory, A. (1999). Audit committee activity and agency costs. Journal of Accounting and Public Policy, 18(45), 311-332.

Conger, J. A., Finegold, D., \& Lawler, E. E. (1998). Appraising boardroom performance. Harvard Business Review, 76, 136164.

DeFond, M. L. (1992). The association between changes in client firm agency costs and auditor switching. Auditing, 11(1), 16.

DeFond, M. L., Francis, J. R., \& Wong, T. J. (2000). Auditor industry specialization and market segmentation: Evidence from Hong Kong. Auditing: A Journal of Practice \& Theory, 19(1), 49-66. 
Dopuch, N., Holthausen, R. W., \& Leftwich, R. W. (1986). Abnormal stock returns associated with media disclosures of 'subject to'qualified audit opinions. Journal of Accounting and Economics, 8(2), 93-117.

Fama, E. F., \& Jensen, M. C. (1983). Separation of ownership and control. The Journal of Law and Economics, 26(2), $301-325$.

Ferreira, D., Ferreira, M. A., \& Raposo, C. C. (2011). Board structure and price informativeness. Journal of Financial Economics, 99(3), 523-545.

Greco, G. (2011). Determinants of board and audit committee meeting frequency. Managerial Auditing Journal, 26(3), 208-229

Hahn, P. D., \& Lasfer, M. (2007). Vanishing board meetings: Has governance doomed the board meeting. London: Cass Business School Research Paper.

Hahn, P. D., \& Lasfer, M. (2016). Impact of foreign directors on board meeting frequency. International Review of Financial analysis, 46, 295-308.

Haniffa, R., Yatim, P., Kent, P., \& Clarkson, P. (2006). Governance structures, ethnicity, and audit fees of Malaysian listed firms. Managerial Auditing Journal, 21(7).

Jiraporn, P., Davidson III, W. N., DaDalt, P., \& Ning, Y. (2009). Too busy to show up? An analysis of directors' absences. The Quarterly Review of Economics and Finance, 49(3), 1159-1171.

Kaplan, S. E., \& Williams, D. D. (2013). Do going concern audit reports protect auditors from litigation? A simultaneous equations approach. The Accounting Review, 88(1), 199-232.

Khasharmeh, H. A., \& Aljifri, K. (2010). The timeliness of annual reports in Bahrain and the United Arab Emirates: An empirical comparative study. The International Journal of Business and Finance Research, 4(1), 51-71.

Knechel, W. R., \& Sharma, D. S. (2012). Auditor-provided nonaudit services and audit effectiveness and efficiency: Evidence from pre-and post-SOX audit report lags. Auditing: A Journal of Practice \& Theory, 31(4), 85-114.

Laksmana, I. (2008). Corporate board governance and voluntary disclosure of executive compensation practices. Contemporary Accounting Research, 25(4), 1147-1182.

Lin, Y. F., Yeh, Y. M. C., \& Yang, F. M. (2014). Supervisory quality of board and firm performance: a perspective of board meeting attendance. Total Quality Management \& Business Excellence, 25(3-4), 264-279.

Lipton, M., \& Lorsch, J. W. (1992). A modest proposal for improved corporate governance. The Business Lawyer, 48(1), 5977.

Méndez, C. F., \& García, R. A. (2007). The effects of ownership structure and board composition on the audit committee meeting frequency: Spanish evidence. Corporate Governance: An International Review, 15(5), 909-922.

Menon, K., \& Williams, J. D. (1994). The use of audit committees for monitoring. Journal of Accounting and Public Policy, 13(2), 121-139.

Naveen, L., Daniel, N. D., \& McConnell, J. J. (2013). The advisory role of foreign directors in US firms. Available at SSRN 2023420.

Newton, J. D., \& Ashton, R. H. (1989). The association between audit technology and audit delay. Auditing-a Journal of Practice \& Theory, 8, 22-37.

Pincus, K. V., Bernardi, R. A., \& Ludwig, S. E. (1999). Audit effectiveness versus audit efficiency: Are the two in conflict?. International Journal of Auditing, 3(2), 121-133.

Piot, C., Dumontier, P., \& Janin, R. (2015). IFRS Consequences on Accounting Conservatism in Europe: Do Auditor Incentives Matter?. Available at SSRN 1754504.

Raghunandan, K., \& Rama, D. V. (2007). Determinants of audit committee diligence. Accounting Horizons, 21 (3), $265-279$.

Ramos, R., \& Olalla, M. (2011) Board characteristics and firm performance in public founder- and nonfounder-led family businesses. Journal of Family Business Strategy, 2, 220-31.

Sharma, V., Naiker, V., \& Lee, B. (2009). Determinants of audit committee meeting frequency: Evidence from a voluntary governance system. Accounting Horizons, 23(3), 245-263.

Vafeas, N. (1999). Board meeting frequency and firm performance. Journal of Financial Economics, 53(1), $113-142$.

Wallace, R. S. O., \& Briston, R. J. (1993). Improving the accounting infrastructure in developing countries. Research in Third World Accounting, 2, 201-224.

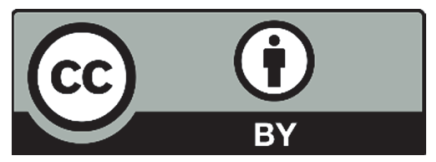

(C) 2021 by the authors; licensee Growing Science, Canada. This is an open access article distributed under the terms and conditions of the Creative Commons Attribution (CC-BY) license (http://creativecommons.org/licenses/by/4.0/). 